DOI https://doi.org/10.30525/978-9934-26-075-9-4

\title{
РОЛЬ ВНУТРІШНЬОЧЕРЕВНОЇ ГІПЕРТЕНЗІЇ У РОЗВИТКУ ПІСЛЯОПЕРАЦІЙНОЇ ЕВЕНТРАЦІЇ
}

\author{
Бодяка В. Ю. \\ доктор медичних наук, \\ завідувач кафедри онкології та радіології \\ Буковинський державний медичний університет \\ м. Чернівиі, Україна
}

Незважаючи на розвиток сучасної медицини, частота розвитку післяопераційної евентрації залишається на досить високому рівні та становить від 0,5 до $2,35 \%$ [2, 5, 7, 11, 14, 18$]$.

Одним із багатьох чинників який безпосередньо призводить до виникнення післяопераційної евентрації $\epsilon$ гостре підвищення рівня внутрішньочеревного тиску, що має місце при гострій кишковій непрохідності, гемоперитонеумі внаслідок травми, набряку очеревини при перитоніті тощо $[1,15,17,19]$.

Вищезазначені ускладнення зустрічаються частіше у невідкладній хірургії, проте розвиток внутрішньочеревної гіпертензії, у ранньому післяопераційному періоді має місце і в абдомінальній онкології, що також може стати одним із чинників розвитку післяопераційної евентрації, оскільки даний контингент пацієнтів $є$ групою підвищеного ризику $[6,12,13]$.

У літературі з'являється все більше публікацій стосовно негативної дії внутрішньочеревної гіпертензії на морфофункціональний стан внутрішніх органів, проте даних щодо впливу останньої на репаративні процеси у ділянці лапаротомної рани, міцність післяопераційного рубця відсутні $[8,9,16]$.

Вивчення в експерименті впливу внутрішньочеревної гіпертензії на морфологічні особливості грануляційної тканини та механічну міцність післяопераційного рубця лапаротомної рани, а також дослідження частоти розвитку післяопераційної евентрації, залежно від рівня внутрішньочеревного тиску, у оперованих хворих на онкологічну патологію органів черевної порожнини, дасть змогу краще зрозуміти негативний вплив останньої у розвитку даного післяопераційного ускладнення. 
Тому метою дослідження було - експериментально та клінічно вивчити роль внутрішньочеревної гіпертензії у розвитку післяопераційної евентрації.

Експеримент проведено на 204 лабораторних щурах, яким виконано серединну лапаротомію та зведено краї м'язово-апоневротичного шару передньої черевної стінки вузловими швами. Основну групу склали 144 тварини, яким створювали внутрішньочеревну гіпертензію за власним способом, шляхом імплантації у черевну порожнину латексного контейнеру з певною кількістю фізіологічного розчину [4]. Групу порівняння склали 96 тварин, яким після виконання лапаротомії у черевну порожнину введено порожній латексний контейнер.

Забір біологічного матеріалу проводили на 1-у, 3-ю та 5-у доби після створення внутрішньочеревної гіпертензії, шляхом висічення м'язовоапоневротичного шару передньої черевної стінки. Механічну міцність післяопераційного рубця визначали у вищезазначені терміни, шляхом вимірювання рівня внутрішньочеревного тиску у момент розриву післяопераційного рубця лапаротомної рани [10].

3 метою вивчення частоти розвитку післяопераційної евентрації, залежно від рівня внутрішньочеревного тиску, нами обстежено 122 оперованих хворих на злоякісні новоутворення органів черевної порожнини, яким виконано серединну лапаротомію. Залежно від середнього рівня внутрішньочеревного та абдомінального перфузійного тисків пацієнти розподілені на три групи [3, с. 16].

Отримані результати дослідження вказують, що виникнення внутрішньочеревної гіпертензії вкрай негативно впливає на дозрівання грануляційної тканини лапаротомної рани, проте слід зазначити певну залежність - чим вищий рівень сталого внутрішньочеревного тиску, тим пізніше настає адаптація репаративних процесів у ділянці лапаротомної рани.

Створена внутрішньочеревна гіпертензія призводить до зниження механічної міцності післяопераційного рубця лапаротомної рани. Ступінь негативного впливу внутрішньочеревної гіпертензії на міцність післяопераційного рубця обернено пропорційна рівню внутрішньочеревного тиску.

Результати проведеного клінічного дослідження вказують на певну залежність між рівнями внутрішньочеревного та абдомінального перфузійного тисків та частотою розвитку післяопераційної евентрації, що доводить вірогідна різниця частоти розвитку останньої у групах пацієнтів з вищим рівнем внутрішньочеревного тиску та відповідно нижчим рівнем абдомінального перфузійного тиску. 


\section{Література:}

1. Корик В.Е., Клюйко Д.А., Бут-Гусаим Г.В., [и др.]. Абдоминальный компартмент синдром: современные аспекты диагностики и лечения. Журнал «Военная медищина». 2016. № 3. С. 127-133.

2. Баймышев Е.С., Абзалиев К.Б., Карибеков Т.С. Профилактика послеоперационной эвентрации. Вестн. хирургии им. И.И. Грекова. 1988. № 7. С. 119-120.

3. Бодяка В.Ю. Порівняльна характеристика способів вимірювання внутрішньочеревного тиску. Клінічна анатомія та оперативна хірургія. 2010. T. 9, № 4. С. 73-76.

4. Бодяка В.Ю. Спосіб моделювання внутрішньочеревної гіпертензії. Клінічна анатомія та оперативна хірургія. 2012. Т. 11, № 3. С. 111-113.

5. Бойко В.В., Савві С.О., Житецький В.В., Новиков Є.А. Профілактика евентрацій після повторних операційна органах черевної порожнини. Харківська хірургічна школа. 2012. № 2 (53). С. 11-12.

6. Воровський О.О. Превентивна абдомінопластика з використанням поліпропіленового протеза під час первинної лапаротомії у хворих похилого й старечого віку як спосіб профілактики післяопераційних дефектів черевної стінки. Клінічна хірургія. 2013. № 11. С. 34-37.

7. Жидецкий В.В. Профилактика и хирургическое лечение послеоперационных эвентраций. Медищина сьогодні $і$ завтра. 2012. № 2 (55). C. $145-149$.

8. Каминский И.В. Эвентрация и послеоперационный перитонит. Украӥнський Журнал Хірурсї. 2009. № 2. С. 73-75.

9. Морар I.К., Іващук О.І., Давиденко І.С., [та ін.]. Особливості формування грануляційної тканини навколо елементів сітчастого імплантату передньої черевної стінки при застосуванні гіалуронової кислоти в експерименті. Клінічна та експериментальна патологія. 2015. № 2 (52). C. 120-126.

10. Морар I.К., Іващук О.І., Давиденко І.С., Власов В.В., Бодяка В.Ю. Особливості формування грануляційної тканини навколо елементів сітчастого імплантату передньої черевної стінки при застосування гіалуронової кислоти в експерименті. Клінічна та експериментальна патологія. 2015. Т. 14, № 2 (52). С. 120-125.

11. Бодяка В.Ю., Іващук О.І., Давиденко І.С. Патоморфологічні зміни внутрішніх органів за дії підвищеного внутрішньочеревного тиску в експерименті. Клінічна та експериментальна патологія. 2013. T. XII, № 2 (44). C. 18-20.

12. Петрович Г.В. Гістологічні аспекти застосування проленових алотрансплантатів 3 метою запобігання післяопераційної евентрації 
в експерименті. Буковинський медичний вісник. 2010. Т. 14, № 1 (53). C. $128-130$.

13. Морар І.К., Іващук О.І., Бодяка В.Ю., [та ін.]. Післяопераційна евентрація. Клінічна та експериментальна патологія. 2017. Т. 16, № 1 (59). С. 177-181.

14. Полынский А.А., Чернышов Т.М. Эвентрация. Принципы диагностики и лечения. Журнал Гроденского государственного медииинского университета. 2014. № 2 (46). С. 10-14.

15. Антонюк О.С., Ахрамєєв В.В., Головня П.Ф., [та ін.]. Проблема евентрації у невідкладній хірургії. Медицина транспорту України. 2005. № 1 . С. 50-52.

16. Саенко В.Ф., Белянский Л.С. Эвентрация, причины, профилактика, лечение. Клінічна хірургія. 2005. № 2. С. 47-51.

17. Іващук О.І., Бодяка В.Ю., Морар І.К., [та ін.]. Синдром абдомінальної компресії як клінічна проблема сучасної невідкладної хірургії. Клінічна анатомія та оперативна хірургія. 2011. Т. 10, № 4. С. 81-86.

18. Синдром интраабдоминальной гипертензии / Б.Р. Гельфанд, Д.Н. Проценко, П.В. Подачин, и др.; под ред. В.С. Савельева. Новосибирск: Сибирский успех, 2008: Партнеры Сибири, 2008. 32 с.

19. Совцов С.А., Шестопалов С.С., Михайлова С.А. Динамика измерения внутрибрюшного давления у больных после операции на органах брюшной полости. Пермский медицинский журнал. 2005. Вып. 22, № 3. С. 89-93.

20. Boulliot J.L., Servajean S., Pozzo A., [at al.]. Eventration of the abdominal wall. Rev. Prat. 2003. N. 15. P. 1677-2.

21. Gurjar V., Halvadia B.M., Bharaney R.P., [et al.]. Study of two techniques for midline laparotomy fascial wound closure. Indian J Surg. 2014. Vol. 76 (2). P. 91-4. 